\title{
Slavoj Žižek, Less Than Nothing: Hegel and the Shadow of Dialectical Materialism
}

\author{
London: Verso, 2012, 1056pp., ISBN 978-1844678976
}

\author{
Reviewed by Agon Hamza \\ Research Centre of the Slovenian Academy of Sciences and Arts
}

\begin{abstract}
As is well known, Slavoj Žižek's philosophical system is informed by three orientations: Hegelian philosophy, Lacanian psychoanalysis and a Marxist critique of ideology. While they are not symmetrically present in his work, Žižek proposes not only a diametrically different reading of these traditions, but also a conceptual and systematic re-organization and replacement of them into a new philosophical terrain. In a superficial analysis of his works from The Sublime Object of Ideology published in 1989 until his most recent Absolute Recoil, one cannot fail to see a shift in his references: Lacan has absolute privilege over Hegel and Marx, whereas from The Parallax View (2006) onwards, Hegel occupies that position. In the preface to The Sublime Object of Ideology, Žižek argues that
\end{abstract}

the only way to "save Hegel" is through Lacan, and this Lacanian reading of Hegel and the Hegelian heritage opens up a new approach to ideology, allowing us to grasp contemporary ideological phenomena... without falling prey to any kind of "post-modernist" traps (such as the illusion that we live in a "post-ideological” condition) (Žižek 1989: 7).

For Žižek, Hegel and Lacan are inseparable. Let us precede with one more quotation, from For They Know Not What They Do, a sequel to The Sublime Subject of Ideology:

As with The Sublime Object of Ideology, the theoretical space of the present book is moulded by three centers of gravity: Hegelian dialectics, Lacanian psychoanalytic theory, and contemporary criticism of ideology. These three circles form a Borromean knot: each of them connects the other two; the place that they all encircle, the "symptom" in their midst... The three theoretical circles are not, however, of the same weight: it is their middle term, the theory of Jacques Lacan, which is-as Marx would say-"the general illumination which bathes all the other colors and modifies their particularity” (Žižek 2002: 2). 
Let us put this in schematic terms: Žižek's Lacan is the exact opposite of the Lacan present in Anglo-Saxon academia, a post-structuralist close to Derrida or even Deleuze. For Žižek, Lacan is separate from the whole post-War French philosophical tradition and as such, he is much closer to Hegel than to anyone else-albeit the fact that Lacan didn't know it. However, in his recent work this seems to change. For some time now and in his major project of re-reading Hegel, Žižek seems to have placed Hegel in the determining role (McGowan 2013: 31-53): both for a reading of Marx's critique of political economy and Lacan's psychoanalytic theory. Žižek is going back more and more to Freud's notion of drive to read Hegel. Despite his indebtedness to Lacan, his main master is Hegel. That is why Hegel is the ground upon which Žižek creates his political project. Even further back, in his third "major" book, Tarrying with the Negative, he develops the Hegelian reversal of Marx. Accordingly, Žižek goes against the traditional Marxist "Marx critique of Hegel." Let us proceed from this point. Slavoj Žižek is often accused of being a charlatan, an inconsistent thinker whose writings are only a bulk of insubstantial content. Isn't this the line that all of his critics constantly repeat? They begin by pointing out that he has no system of philosophy, and end up arguing that he constantly fails in doing what he promises he will do. A shocking surprise to all these critics is Hegel's Phenomenology of Spirit: if there was a book that is truly inconsistent, that covers a very wide range of topics, from consciousness, to scepticism, to art, to religion, without an underlying premise, than it is that book (cf. Pinkard 2000: 256-65). Furthermore, Hegel faced the same critiques as Žižek. Shall we then say that Žižek, just like Hegel, is an unsystematic thinker full of contradictions, and close this review right at this point? A little difficulty arises here, precisely at the term "contradiction." The elementary response to these accusations is that contradiction is inscribed in the very dialectical process of thinking. Dialectical thinking and/or processes are based, grounded, on contradiction. A system of thought (but not only of it, it goes the same way for political systems, etc.) is based on a consistent Whole. The Whole as such is structured on its symptoms, excesses, and so on. In this sense, isn't this precisely Žižek's Hegel? The philosophical studies on Hegel, particularly in the Anglo-Saxon world, have been predominantly focused in providing a non- or anti-metaphysical Hegel. Let us quote a paragraph from Less Than Nothing, in which Žižek fights against that reading of Hegel:

The predominant Hegelian strategy that is emerging as a reaction to this scarecrow image of Hegel the Absolute Idealist offers a "deflated" image of Hegel freed of ontological- metaphysical commitments, reduced to a general theory of discourse, of possibilities of argumentation. This approach is best exemplified by so-called Pittsburgh Hegelians (Brandom, McDowell), and is ultimately advocated also by Robert Pippin, for whom the point of Hegel's thesis on Spirit as the “truth” of Nature (Žižek 2012: 237). 


\section{Book reviews / Рецензии}

He continues:

Such a "deflated" image of Hegel is not enough; the post-Hegelian break must be approached in more direct terms. True, there is a break, but in it Hegel is the "vanishing mediator" between its "before" and its "after"; between traditional metaphysics and post-metaphysical nineteenthand twentieth-century thought. That is to say, something happens in Hegel, a breakthrough into a unique dimension of thought, which is obliterated, rendered invisible in its true dimension, by post-metaphysical though! (Žižek 2012: 239).

The question we need to ask is thus a simple one: why does Žižek need Hegel ? $^{1}$ And, which Hegel do we get in Žižek's work? At an elementary level, Žižek's Hegel is the anti-deflated Hegel, as most consistently developed by Pippin, whose aim is to defend bourgeois philosophy. ${ }^{2}$ As a result, we get both an ontologically and politically deflated Hegel, who theorized the bourgeois state and its effects.

When he famously calls for "the return from Marx to Hegel," what Žižek really means is the reversal of the standard twentieth-century Marxist approach of dismissing Hegel (most notably represented by Althusser). His project can be thus boiled down to the following thesis: contemporary Marxism should not be grounded on Marx's reading of Hegel, but rather on the premises of how Hegel would read Marx, through Lacanian lenses.

How does Hegel's philosophy function? Philosophy intervenes when and where the figure of consciousness has grown old. In Hegel's words:

This lesson of the concept is necessarily also apparent from history, namely that it is only when actuality has reached maturity that the ideal appears opposite the real and reconstructs this real world, which it has grasped in its substance, in the shape of an intellectual realm. When philosophy paints its grey in grey, a shape of life has grown old, and it cannot be rejuvenated, but only recognized, by the grey in grey of philosophy; the owl of Minerva begins its flight only with the onset of dusk (Hegel 1991: 23).

Again, if we follow Žižek we can argue against Marx’s Thesis 11, according to which, throughout the history of philosophy, philosophers have only interpreted the world; occupying the position of the beautiful soul, refusing to engage in it and thus transforming it. Isn't the exact opposite true? Apart from Hegel, every other philosopher had a master plan

See Hamza (2015).

2 See his review of Žižek's Less Than Nothing (Pippin 2012-13). Also, see Adrian Johnston (2012: 371-418) and Žižek's response (2014). 


\section{Book reviews / Рецензии}

of an ideal form of social organisation: from Plato onwards, each philosopher wrote or had his Republic. The only one who doesn't have such a project, and whose critique Marx is predominantly directed at, is Hegel! Hegel is the philosopher who does not particularly look to the future: recall his comments on the United States and Russia, where (from an eighteenth-century perspective) he says that although it is too early to tell, the future lies with them.

The most anti-Hegelian position would be to see his conceptualization of the State as a closed, rational one. If anything, his State is open to all contingencies, unexpected events, reversals, and so forth. It is precisely this openness that grants Žižek the possibility of rethinking communism in Hegelian terms.

\section{Bibliography}

Hamza, Agon (2015). “Going to One’s Ground: Žižek’s Dialectical Materialism.” In Slavoj Žižek and Dialectical Materialism, eds. Agon Hamza and Frank Ruda, 16375. New York: Palgrave.

Hegel, G. W. F. (1991). Elements of the Philosophy of Right. Ed. Allen B. Wood, trans. H. B. Nisbet. Oxford: Oxford University Press

Johnston, Adrian (2012). "Where to Start?: Robert Pippin, Slavoj Žižek, and the True Beginning(s) of Hegel's System.” Crisis and Critique 1.3: 371-418.

McGowan, Todd (2013). “Hegel as a Marxist: Žižek's revision of German Idealism.” In Žižek Now: Current Perspectives in Žižek Studies, eds. Jamil Khader and Molly Anne Rothenberg, 31-54. Cambridge: Polity.

Pippin, Robert (2012-13). “Back to Hegel?” Meditations 26.1-2:7-29. http://www.mediationsjournal.org/articles/back-to-hegel.

Žižek, Slavoj (1989). The Sublime Object of Ideology. London: Verso.

Žižek, Slavoj (2002). For They Know Not What They Do: Enjoyment as a Political Factor. London: Verso.

Žižek, Slavoj (2012). Less Than Nothing: Hegel and the Shadow of Dialectical Materialism. London: Verso.

Žižek, Slavoj (2014). Absolute Recoil: Towards a New Foundation of Dialectical Materialism. London: Verso. 